\title{
Obituary
}

\section{Professor Christine A. Bellamy}

It is with great sadness to note the passing of Professor Christine A. Bellamy a year ago in May 2017. Professor Bellamy was an outstanding academic who has left a lasting legacy of academic thought relating to our understanding of the institutional contexts of eGovernment. Her seminal work, with Professor John Taylor, titled Governing in the Information Age (1998), may be 20 years old, but it is still essential reading for all eGovernment scholars. Her work is especially pertinent to this journal, as the title of the journal Information Polity pays homage to her theorizing with John Taylor about the inherent way that information and new technologies are interwoven within the contemporary polity (1994). As such, the journal itself is a tangible manifestation of her academic legacy. Professor Bellamy was well known to the scholarly eGovernment community, her enthusiasm and passion for our subject area, her exemplary academic standards, as well as her academic insight and intuition will be sorely missed. On a personal note, both the current Editors-in-Chief of Information Polity would like to acknowledge the personal and professional influence of Professor Bellamy during their formative academic years.

The Obituary Notice below is published with the kind permission of Sage Publishing and first appeared in Teaching Public Administration in 2017.

Editors-in-Chief

Albert Meijer

William Webster

\section{References}

Bellamy, C. and Taylor, J. (1998) Governing in the Information Age. Open University Press.

Bellamy, C. and Taylor, J. (1994) Exploiting IT in Public Administration - Towards and Information Polity. Public Administration, 72(1): 1-13.

\section{Obituary notice for the Joint University Council: Professor Christine A. Bellamy ${ }^{1}$}

Perri 6, School of Business and Management, Queen Mary University of London, London, UK. Charles Raab, School of Social and Political Science, University of Edinburgh, Edinburgh, UK. Sandra Odell, Nottingham Trent University, Nottingham, UK.

Colleagues active in the (UK) Joint University Council (JUC) and in its Public Administration Committee (PAC) will be sad to hear of the death on 25 May 2017 of Professor Christine A. Bellamy.

\footnotetext{
${ }^{1}$ Kindly reprinted with permission from Sage. First published in Teaching Public Administration (2017), 35 (3): 1-3.
} 
Professor Bellamy was the chair of the JUC between 1998 and 2002. She also chaired its PAC between 1993 and 1996. For her service, the JUC gave Chris the exceptional honour of a lifetime honorary fellowship. During her time as JUC Chair, Chris worked hard to improve its 'ailing' financial situation and introduced new administrative procedures to improve the efficiency and running of the JUC. Until recently she was a member of the Editorial Board of the Public Policy and Administration Journal and a regular attender at PAC meetings.

In a lifetime of outstanding service to the profession, Chris played leading roles in the Academy of Social Science, for which she chaired the Nominations Committee, in the subpanel for Political Science and International Relations in the Research Assessment Exercise of 2008, in many committees of the Economic and Social Research Council (ESRC), and as a Member of the Steering Group for ESRC and British International Studies Association and the Political Studies Association: International Benchmarking Review of UK Politics and International Studies.

Educated at Twickenham County Grammar School, Chris completed her PhD at Nottingham University in 1975. Much of her career was spent at Nottingham Trent University, formerly Trent Polytechnic. Chris became Associate Dean (Research and Postgraduate Studies) in the University's College of Business, Law and Social Sciences. A great institution builder and inspirational leader, she brought together a team of distinguished research professors including Nicholas Tilley, Irene Hardill and Peter Dwyer.

Chris's own research and publications are of continuing major importance in the study of public administration. Her 1988 monograph, Administering central-local relations, 1871-1919 remains the definitive study on the Local Government Board, which was the first significant British central ministry for local government, of its role in the administration of the Poor Law and the origins of the Ministry of Health. In that work, Chris not only explored the high politics and the administrative capacities of the Board and its changing relationships with councils, medical officers of health and the poor law guardians, but located it in the grand traditions of normative British political thought.

Chris devoted much of her career to developing a very distinctive account of the capacities and capabilities of the state, using British government as her case study and deploying her formidable combination of long term historical perspective and appreciation of social science theory. Against both the fashionable utopianism that computing would enable the 'reinvention' of government, and against pessimism that technology would necessarily introduce the panopticon dystopia, Chris focused on the handling of information, client records, case files, project files, accounting and bookkeeping information, and the like, in British government to show technology does not make the state. Rather, enduring institutionalized practices of public services and parliamentary accountability shape the uses of technology. Her detailed archival research demonstrated that the British state had neither capabilities nor intentions for either drastic integration or comprehensive surveillance. Governing in the information age, written with John Taylor, redirected the entire international literature on 'digital government'. It refocused the study of e-government toward institutional perspectives. Her ESRC-funded work in the 2000s on how public services strike different settlements between rival imperatives for joint working and client confidentiality stands preeminent in its field.

Often ferociously critical of fashionable nostrums in political science and practical public administration, Chris argued for taking both institutions and empirical nuance seriously. Her deep commitments to combining craft of research with rigorous design and to teaching led to her widely used textbook, Principles of methodology. She worked until her death on her administrative history of identity management in British government from the nineteenth century to the present.

A keen and expert gardener and yachtswoman, Chris was a devoted grandmother and a loyal friend. She is survived by her husband David, daughter Alice and grandchildren, Emily and Thomas. 


\section{Conflict of interest}

The authors declared no potential conflicts of interest with respect to the research, authorship, and/or publication of this article.

\section{Author biographies}

Perri 6 is Professor in Public Management at Queen Mary University of London. Charles Raab is Professorial Fellow in Politics and International Relations, in the School of Social and Political Science at the University of Edinburgh. Both were co-authors and research collaborators with Christine Bellamy from the late 1990s until her final years. Sandra Odell is the Secretary of the JUC and worked closely with Christine Bellamy at Nottingham Trent University. 